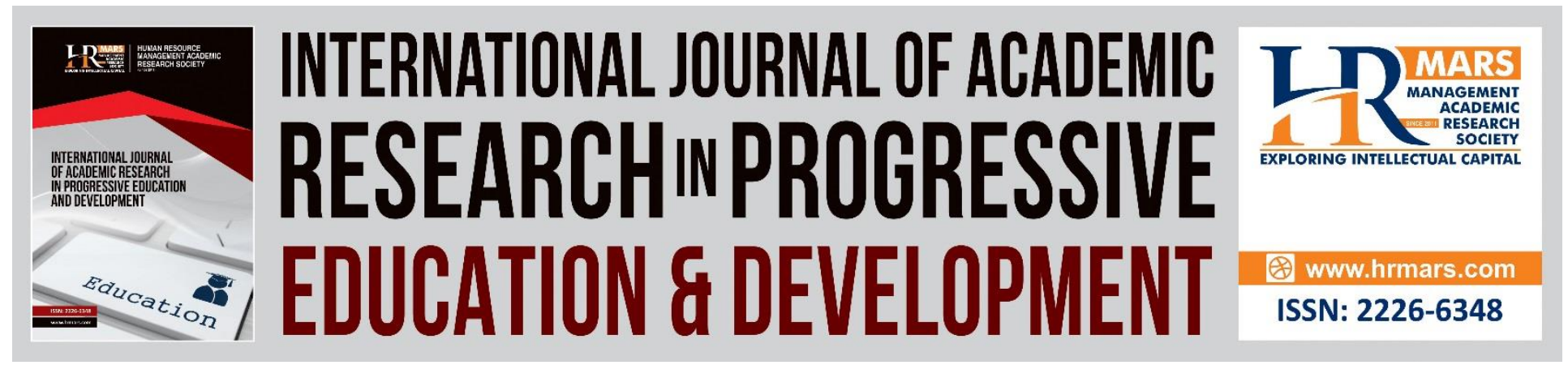

\title{
The Effects of the Multimedia Interactive Module of Making Clothes (MIMC) on Students' Understanding of the Concepts of Making Clothes in the Home Science Subject
}

\author{
Baity Bujeng, Arasinah Kamis, Farah Najwa Ahmad Puad
}

To Link this Article: http://dx.doi.org/10.6007/IJARPED/v9-i2/7492

DOI:10.6007/IJARPED/v9-i2/7492

Received: 11 April 2020, Revised: 13 May 2020, Accepted: 10 June 2020

Published Online: 23 July 2020

In-Text Citation: (Bujeng et al., 2020)

To Cite this Article: Bujeng, B., Kamis, A., \& Puad, F. N. A. (2020). The Effects of the Multimedia Interactive Module of Making Clothes (MIMC) on Students' Understanding of the Concepts of Making Clothes in the Home Science Subject. International Journal of Academic Research in Progressive Education and Development, 9(2), 483-493.

\section{Copyright: (C) 2020 The Author(s)}

Published by Human Resource Management Academic Research Society (www.hrmars.com)

This article is published under the Creative Commons Attribution (CC BY 4.0) license. Anyone may reproduce, distribute, translate and create derivative works of this article (for both commercial and non-commercial purposes), subject to full attribution to the original publication and authors. The full terms of this license may be seen at: http://creativecommons.org/licences/by/4.0/legalcode

\section{Vol. 9(2) 2020, Pg. 483 - 493}

Full Terms \& Conditions of access and use can be found at http://hrmars.com/index.php/pages/detail/publication-ethics 


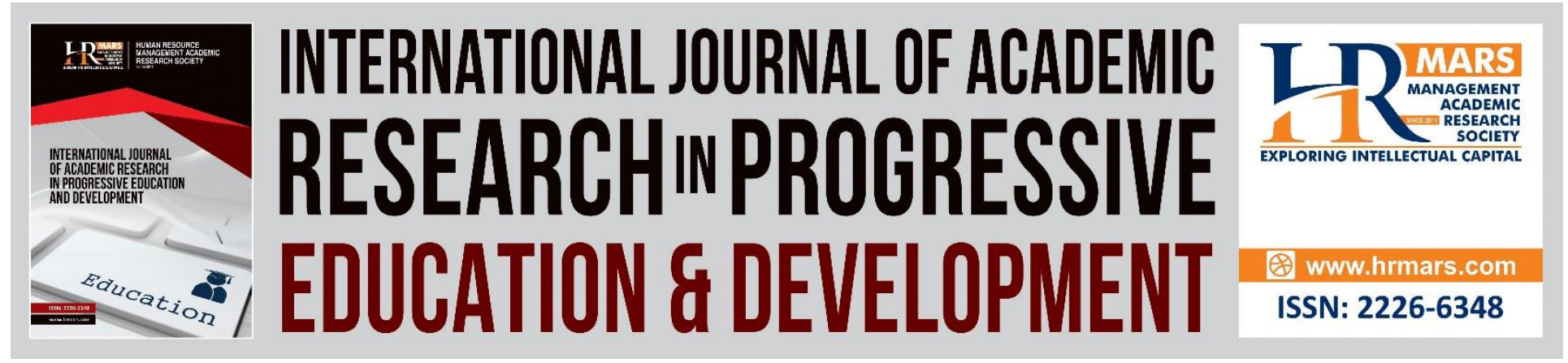

\title{
The Effects of the Multimedia Interactive Module of Making Clothes (MIMC) on Students' Understanding of the Concepts of Making Clothes in the Home Science Subject
}

\author{
Baity Bujeng ${ }^{1}$, Arasinah Kamis², Farah Najwa Ahmad Puad ${ }^{3}$ \\ ${ }^{1}$ Institute of Teacher Education Sarawak Campus, Bakam Road, 98009 Miri, Sarawak, ${ }^{2,3}$ Faculty \\ of Tehnical and Vocational Education, University Pendidikan Sultan Idris, 35900 Tanjong Malim, \\ Perak, Malaysia
}

\begin{abstract}
The Multimedia Interactive Module of Making Clothes (MIMC) is developed for the teachers to learn and facilitate (LFc) the teaching of the Making Clothes topic in the Home Science (HS) subject in the Malaysian schools. The purpose of this study is to test the effects of using the MIMC on students' understanding of the basic concepts of making clothes. This is a quantitative study employing the quasi-experimental method of pre-and post-test. The study used cluster sampling to select 73 Form Four HS students who were then divided into the treatment and control groups. A total of 37 students of the treatment group were taught the topic of Making Clothes using the MIMC while 36 students of the control group were taught using the conventional method. The data were analyzed using the SPANOVA test. The findings show that the use of MIMC has a significant impact on the students' understanding with $p<0.05$. The implications of this study are that the use of MIMC effectively increases the students' understanding as well as the mastery of the difficult and abstract making-clothes concepts. In conclusion, multimedia-based teaching and learning yield better outcomes than those of the conventional method.
\end{abstract}

Keywords: Multimedia Interactive Module, Making Clothes, Home Science, Understanding.

\section{Introduction}

The goal of Technical and Vocational Education (TVE) is to train knowledgeable and skilled graduates who are capable of producing high-grade products and providing quality services (Zakaria \& Aisyah, 2017; Reeve, 2016). Along with the development of globalization, economic and technological advancement, TVE has undergone several phases of changes and transformation during the 10th and the 11th Malaysia Plan. These changes include the Ministry of Education's (MOE) efforts in raising the level of TVE's quality; in particular the curriculum was revamped to be in line with the $21^{\text {st }}$-Century education goals (Ahmad, Jalani \& Hasmori, 2015). 
According to Smaldino, Lowther \& Russell (2012), the $21^{\text {st }}$-century learning environment encompasses learning strategies that are teacher-centered or student-centered; integration of technology, media, and material to support learning; and variety of learning contexts. The MOE also emphasizes the element of technology literacy, coupled with the application of information and communication so that the teaching and learning process is more effective and of better quality (Sarkar, 2012); learning needs can then be met and goals achieved (Karaci, Akyuz, \& Arici 2018). According to Ma \& Pendergast (2010), the Home Science Education is also aligned with the changes of the $21^{\text {st }}$-Century learning.

The Home Science (HS) teaching and learning activities comprise primarily hands-on experience or training, 80 percent practical work and 20 percent theoretical learning (Zakaria \& Aisyah, 2017; Mohamed, Kamis \& Ali, 2016). The students' theoretical knowledge and practical skills of the clothing and sewing component are still at a moderate level (Tee et al., 2016; Rubi, Mohamed \& Sulaiman, 2014). Their understanding of the making-clothes topic is also low and they consider it very difficult to master (Bujeng, Kamis, Mohamed \& Puad, 2018). According to Castro, Andres and Prestoza (2018), students' learning outcomes can be improved if they are often exposed to interesting and encouraging T\&L methods. It cannot be denied that, in general, the teaching techniques are quite boring because teachers are still using the traditional teaching methods to deliver the lessons (Castro et al., 2018; Cyril, 2016; Yap, 2016).

Undoubtedly, the ICT and multimedia-based teaching and learning methods have proven to be effective and efficient, capable of helping the students to achieve understanding, acquire skills (Karaci et al., 2018; Hung, Kinshuk \& Chen 2017; Linder, Eital, Strobel \& Koller, 2016; Eital, 2015), maintain memory consistency (Hung et al., 2017; Yap, 2016; Cyril, 2016, Yuskel and Yuskel, 2015), and thereby improve the motivation (Yanika, Moon, Sharon, Alan \& Sally, 2017; Yap, 2016). Students are more excited and attentive if the teachers use ICT in their teaching (Bujeng et al., 2018; Yanika et al., 2017; Pusso \& Ahmad, 2016). The purpose of the study is to test the effects of using the MIMC on the Form-Four students' achievement in the topic of making clothes.

\section{Research Questions}

1. Are there positive effects of using the MIMMC as a teaching tool on achieving the understanding of making clothes?

\section{Hypothesis}

Ho1 The use of Multimedia Interactive Module of Making Clothing (MIMC) does not affect the understanding of making-clothes concepts.

\section{Literature Review}

\section{Module-based Learning}

Modules are small complete sections that are closely related to one other (Russell, 1974). In addition, a module is also a unit of teaching and learning that deals with a particular topic systematically and sequentially, so that it is easier for students to learn and master the content of the unit (Noah \& Ahmad, 2005) easily, quickly and accurately; with a facilitator or without one (Ahmad, 2016). A module is a teaching package, the activities of which are related to the concepts of a specific subject unit. According to Ahmad (2016), the approaches and activities of a module 
are often used by various parties to produce a variety of materials, tools, resources and guides to achieve the stated goals. Previous studies have shown that the modules-based learning has a positive impact on the students as well as teachers. The study by Zuraini (2014) shows that the use of the narrative-approach modules has succeeded in raising learning motivation, increasing involvement in learning, as well as improving writing skills among the low-achievement pupils. Noor Miza (2015) introduced the ProCom Module to help pre-school children to master communication skills and stimulate their interest in learning Madmor et al. (2016) found that the Buzan Mind Map module improved the students' thinking skills and at the same time, enhanced their academic achievement. In addition, the findings also indicate that there was a moderate positive relationship between the degree of mastery of the module and the achievement of good grades in academics. Through the use the module, the students understood the subjects in a greater depth, (Madmor et al., 2016; Wingo, Thomas, Thompson \& Cook, 2015) and their motivation for learning also increased (Wingo et al., 2015). In addition, the implementation of the module-based teaching and learning will enable pupils to master technical skills and acquire practical knowledge in specific areas (Rahman, Hasbullah \& Zahari, 2016).

\section{Interactive multimedia-based Learning}

Multimedia is the use of a variety of artistic or communicative media for the purposes of expression, communication or dissemination of information; it combines two or more elements such as texts, graphics, audios, videos, (Smaldino et al., 2012; Jono, Aziz, Ibrahim \& Noh, 2012) animations and other tools such that the users can communicate, navigate, create and interact by employing the various functions of the package (Khan, Bibi \& Hasan, 2016; Lachs, 2010). The concept of interactivity is a criterion that should be present in a piece of multimedia software developed (Jono et al., 2012); interactive activities can motivate students to learn the concepts of a topic or subject (Yanika et al., 2017). The Cognitive Theory of Multimedia Learning (CTML) by Mayer (2014) says that a combination of text and pictures is better than merely displaying texts or pictures alone. The memory of things stays longer if someone is presented with the material displayed with a combination of pictures and audio. The combination of several media is important so that the complicated and abstract concepts can be delivered at once (Linder et al., 2016; Eital, 2015; Lachs, 2010).

Studies of the multimedia application in the classroom often say that there are positive impacts on teaching and learning. It is found that the achievements of learning objectives and scores are better after students are taught through multimedia presentations, which are a combination of text and pictures. Students are more attentive and engaged when the teaching and learning are multimedia-based rather than text-based (Eital, 2015). Students' knowledge acquisition and content understanding are at a high level after they are taught using a combination of pictures and text. According to Linder et al. (2016), image elements of the multimedia presentations can improve students' performance.

Teaching and learning using the multimedia tools have a positive effect of improving students' achievement in a subject. According to Schrum and Levin (2015), the level of students' learning achievement does not only rely on the standards of teaching and assessments, but also the integration of technology in T\&L. The inclusion of ICT in the instructions will be more effective if the learning outcomes are cognitive-shaped (Yasak \& Alias, 2015). In tandem with this 
statement, the study of Madar and Hashim (2011) found that the cognitive achievement of engineering students was better after they were taught using an animated graphic tool. The practical skills and academic achievements of students increased after they were taught using the multimedia method (Yuksel \& Yuksel, 2015). The use of multimedia benefits the students in these aspects: higher rate of knowledge acquisition, deeper understanding and keener interest, as well as ability to recall what has been learned (Mohd Zin et al., 2012). The video elements contained in the multimedia tools elevate the teachers' teaching process to a higher plane of effectiveness. This notion was proven through a study by El-Sayed and El-Sayed (2012) and Cyril (2016); they found that video-based teaching using ICT was more effective.

\section{Multimedia Interactive Module of Making Clothes (MIMC)}

MIMC is a teaching tool with the support of ICT-based media and technology; it is designed to help the Home Science (HS) teachers to teach the topic of making clothes (Bujeng, Kamis, Hussain, Rahim \& Soenarto, 2019), which is part of the knowledge-based practical learning. According to Tee et al. (2016), theoretical learning is deemed to have been attained when the students achieve a certain level of understanding that includes the explanation and discussion of concepts in the classroom. The students' practical training consists of the acquisition of technical skills based on the theory learned and applied in practical classes or everyday life. This means, students need to understand and master the theory of sewing processes first, before they can apply that knowledge in the practice of making clothes. Bujeng et al. (2018) found that the majority of HS students needed help in the forms of animations, videos, simulations and diagrams to understand the sewing processes that were considered to be difficult and abstract. Accordingly, the MIMC has been developed by incorporating various media elements such as sound, animations, videos, simulations, diagrams and text (Bujeng et al., 2019). The applications of the three learning theories, namely Behaviorism, Cognitivism and Social Constructivism were also considered in the development of the MIMC. The MIMC has a good validity value of 82.5 per cent and a high reliability value of .92 (Bujeng et al., 2019).

\section{Research Methodology \\ Research Design}

This study uses the quasi-experimental design to test the effects of the MIMC usage on the students in achieving understanding of making clothes. Quasi means to have some but not all of the experimental features. It means the design of the study is similar to experiments but not entirely (Holmes, 2014). The quasi-experimental design differs from the full experimental design in the presence of the control groups and treatment groups. Selection of respondents in the quasi-experimental design is not randomly done, and this is another difference between the former and the full experimental design (Creswell, 2014; Holmes, 2014)

\section{Sample of the Study}

A total of 73 Form-Four HS students from the southern zone of Sarawak were selected through random sampling for the purpose of this study. The students were divided into two groups: 37 in the treatment group and 36 in the control group. The respondents consist of 20 males and 53 females. The racial composition of the male respondents is as follows: nine Malays, one Chinese 
and 10 Sarawak Natives. As for the female respondents, there are 16 Malays, five Chinese and 32 Sarawak Natives. The ethnic breakdown of the total number of respondents is as follows: 25 Malays, 6 Chinese, and 42 Sarawak Natives. A sample size exceeding 30 people per group is sufficient to meet the minimum sample requirement of each group of the experiment (Fraenkel, 1996; Talib, 2015).

\section{Research Instrument}

The instrument used in this study is the achievement test for making clothes, with two different teaching methods applied to the treatment group and the control group respectively, and the tests are conducted before and after the treatment. The achievement tests are used to test the students' understanding of the topic of making clothes. In the context of the study, the first achievement test is given to the students within one week before the treatment, and the second test, which is the same as the first, is given after eight weeks of treatment.

\section{Data Analysis}

The data were analyzed and reported in the form of inferential statistics. Inference statistics are data used for interpretation or variables that can explain and describe the relationship between the study variables, and can be related to the characteristics of the respondents under study. After considering the null hypothesis and inference analysis requirements, the researcher chose the ANOVA Split Plot Analysis (SPANOVA) to analyze and report the research data. According to Chua (2014), the SPANOVA test is used to identify the effects before and after the treatment against the dependent variable by comparing the experimental groups.

\section{Finding}

Ho1: The use of MIMC does not affect the understanding of the making-clothes concepts.

Table 1. SPANOVA Test Analysis of Pre-Test and Post-Test Effects on Understanding of the Study Group

\begin{tabular}{llllllc}
\hline \multicolumn{1}{c}{ Source } & & $\begin{array}{c}\text { Type III Sum } \\
\text { of Squares }\end{array}$ & Df & \multicolumn{1}{c}{ Square } & \multicolumn{1}{c}{ F } & Sig. \\
\hline Pre-Post & Huynh-Feldt & 15039.46 & 1 & 15039.46 & 306.88 & .00 \\
Pre-Post * Group & Huynh-Feldt & .09 & 1 & .09 & .002 & .97 \\
Error (Pre-Post) & Huynh-Feldt & 3479.59 & 71 & 49.01 & & \\
\hline
\end{tabular}

Table 1 shows the SPANOVA test analysis of pre-test and post-test effects on understanding of making-clothes concepts of the study group. Due to the Significant Sphericity Mauchly test results, a df value adjustment is performed. The test results, after adjustment using the HuynhFeldt value, indicate that there is an effect on the Pre-Post independent variable $[F(1,71)=$ $306.88, p<.05]$. However, there is no interaction effect between the Pre-Post *Group $[F(1,71)=$ $.002, \mathrm{p}>.05]$. This shows that the MIMC affects the pre-test and post-test comprehension as a whole. The researcher rejects the null hypothesis and reports that the MIMC has an impact on the HS students' understanding of the making-clothes concept. 
INTERNATIONAL JOURNAL OF ACADEMIC RESEARCH IN PROGRESSIVE EDUCATION AND DEVELOPMENT

Vol. 9, No. 2, 2020, E-ISSN: 2226-6348@ 2020 HRMARS

Table 2. SPANOVA Test Analysis Pair of Comparative Scores for Pre-Test and Post-Test Understanding of the Making-Clothes Concepts

\begin{tabular}{ccccc}
\hline (I) Pre-Post & (J) Pre-Post & Mean Difference (I-J) & Std. Error & Sig. $^{{ }^{b}}$ \\
\hline Pre-Test & Post-Test & $-20.30^{*}$ & 1.16 & .000 \\
Post-Test & Pre-Test & $20.30^{*}$ & 1.16 & .000 \\
\hline
\end{tabular}

Table 2 shows the SPANOVA test analysis pairs of comparative scores for the pre-test and posttest understanding of the making-clothes concepts. The comparative pair results show that, after controlling the Type 1 errors using the Bonferroni method, the mean of understanding test for the post-test score surpasses the pre-test score (difference in the mean scores of post-test-pretest $=20.30, p<.05)$. These results show that, there is a significant increase in the mean score value from the pre-test to post-test understanding of the making-clothes concepts.

The Profile Pilots graph in Figure 1 clearly shows that there is an interaction effect between the understanding scores of the treatment group and the control group; the mean score of the treatment group (taught using the MIMC) increases linearly from pre-test to post-test. The mean score of the understanding test for the control group (using conventional method) also increases linearly from pre-test to post-test. The form of this graph confirms that the teaching method using the MIMC is effective in improving the understanding of the making-clothes concepts.

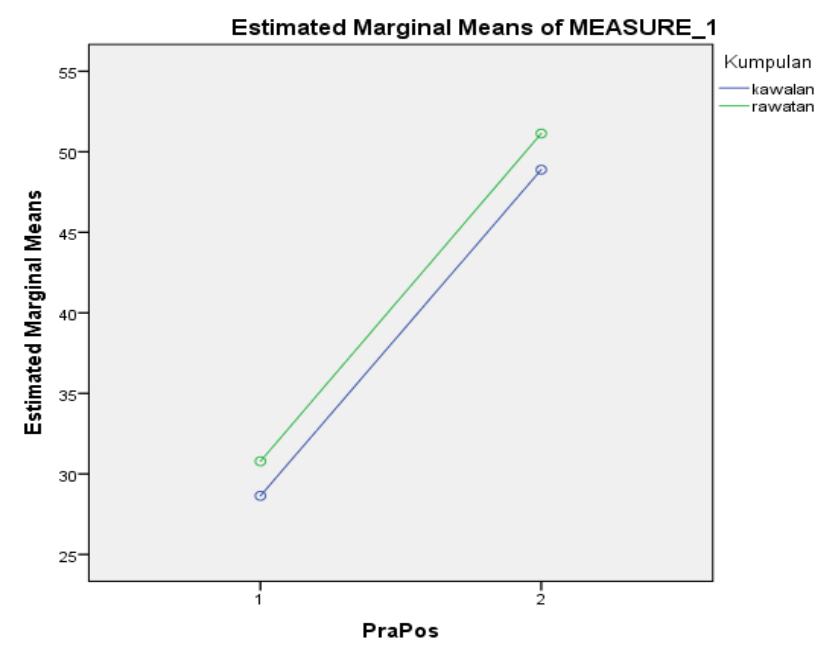

Figure 1. Pre-Test and Post-Test Understanding Scores between group

\section{Discussion}

1. Are there positive effects of using the MIMC as a teaching tool on achieving the understanding of making clothes?

The pre-test and post-test results show that the students in the experimental group have a deeper making-clothes understanding in comparison with the students in the control group. The use of MIMC significantly influences the results of understanding the abstract and difficult concepts of making clothes, demonstrated by the higher post-test score compared with the pretest score, especially for the experimental group. 
Vol. 9, No. 2, 2020, E-ISSN: $2226-6348$ @ 2020 HRMARS

The findings are in line with those of previous studies on the effectiveness of using the multimedia modules. For example, Wingo et al. (2015) and Madmor et al. (2016) found that the module-based teaching improved the students' achievement. In addition, the findings of this study are in line with the studies by Karaci et al. (2018), Hung et al. (2017), Linder et al. (2016), Yasak and Alias (2015), Eital (2015) and Zin et al. (2012); their respective investigations indicate that the applications of multimedia in teaching and learning improved the students' understanding of the subjects or topics.

\section{Conclusion}

The MIMC, developed with technology-based and media-based components, is an effective tool of learning in the 21st Century. Teaching and learning using the MIMC is one way to stimulate the students' interest and draw their attention in the classroom; learning will be more fun and with deeper understanding. As the study findings show, the students' achievement will improve and this in turn will help the teachers to attain the PAK-21 goals. Using the MIMC as a teaching and learning approach has been proven to be superior to the conventional methods to teach the topic of making clothes. This study clearly demonstrates that this alternative method is effective in increasing the students' cognitive, psychomotor and affective capabilities; in the present case, the multimedia software module helps students to gain a clearer understanding of the difficult and abstract concepts of making clothes. Hence, the researcher suggests that further studies be extended to a larger scope, covering schools of all states in Malaysia. The findings can be weighted in proportion to the zone to obtain a more comprehensive picture of this issue.

\section{Corresponding Author}

Baity Bujeng, Institute of Teacher Education Sarawak Campus, Bakam Road, 98009 Miri

Sarawak, Malaysia. Email: baitybujeng@yahoo.com

\section{References}

Ahmad, J. (2016). Modul Motivasi Diri. Ed. Ketiga. Kuala Lumpur: Dewan Bahasa dan Pustaka.

Ahmad, M. J., Jalani, N. H., \& Hasmori, A. A. (2015). TVET di Malaysia: Cabaran dan Harapan. Seminar Kebangsaan Majlis Dekan-Dekan Pendidikan Awam, 2015.

Bujeng, B., Kamis, A., Hussain, M. A. M., Rahim, M. B., \& Soenarto, S. (2019). Validity and Reliability of Multimedia Interactive Making Clothes (MIMP) Module for Home Science Subjects. International Journal if Innovative Technology and Exploring Engineering (IJITEE), 8(8S), 593-596.

Bujeng, B., Kamis, A., Mohamed, S., \& Puad, F. N. A. (2018). Developing an Interactive Multimedia Module for the Topic of Making Clothes: A Requirements Analysis. International Journal of Academic Research in Business and Social Sciences, 8(11), 1688-1700.

Castro, M. R. D., Andres, P. D., \& Prestoza, M. J. R. (2018). The Teaching Techniques and Strategies Use by the Dressmaking Teachers Perceive by the Dressmaking Students. International Journal of Assessment and Evaluation in Education, 8, 48-56. Retrieved from http://ojs.upsi.edu.my/index.php/IJAEE/article/view/1988

Chua, Y. P. (2014). Kaedah dan Statistik Penyelidikan Buku 4. Ujian Univariat dan Multivariat (Edisi ke-2). Selangor: Mc Graw Hill Education. 
Creswell, J. W. (2012). Educational Research: Planning, Conducting and Evaluating Quantitative and Qualitative Research. $4^{\text {th }}$ Ed. Boston: Pearson.

Cyril, M. U. (2016). Effects of Multimedia Instruction on Retention and Achievement of Machining Skills in Mechanical Craft Practice. International Journal of Education and Information Technology, 2(1), 1-7.

Eital, A. (2015). How repeated studying and testing affects multimedia learning: Evidence for adaptation to task demands. Learning and Instruction 41, 70-80.

Fraenkel, J. R., \& Wallen, N. E. (1996). How to Design and Evaluate Research in Education. $3^{\text {rd }}$ Ed. New York: Mc Graw-Hill.

Holmes, W. M. (2014). Using Propensity Scores in Quasi-Experimental Designs. USA: SAGE Publications.

Hung, I.-C., Kinshuk., \& Chen, N.-S. (2017). Embodied interactive video lectures for improving learning comprehensive and retention. Computers \& Education. doi:10.1016/j.compedu.2017.10.005

Jono, M. N. H. H., Aziz, A. A., Ibrahim, M., \& Noh, N. M. (2012). Instructional Design and Learning Theory on the Development of $\mathrm{C}++$ Programming Multimedia Content. Procedia-Social and Behavioral Sciences, 67, 335-344. doi:10.1016/j.sbspro.2012.11.336

Karaci, A., Akyuz, G. B., \& Arici, N. (2018). Effects of Web-based Intelligent Tutoring Systems on Academic Achievement anf Retention. International Journal of Computer Applications, 181(16).

Khan, M. S. H., Bibi, S., \& Hasan, M. (2016). Australian Technical Teachers' Experience of Technology Integration in Teaching. Retrieved 9 October 2016, from https://us.sagepub.com/en-us/nam/open-acces-at-sage

Lachs, V. (2010). Making Multimedia in the classroom. United Kingdom: Taylor \& Francis Books Ltd.

Leow, F. T., \& Neo, M. (2014). Interactive multimedia learning: Innovating classroom education in a Malaysian university. Turkish Online Journal of Educational Technology, 13(2), 99110.

Linder, M. A., Eital, A., Strobel, B., \& Koller, O. (2016). Indentifying processes underlying the multimedia effect in testing: An eye-movement analysis. Learning and Instruction, 47(2017), 91-102.

Ma, A., \& Pendergast, D. (2010). Inovative Pegagogies for Family and Consumer Science/Home Economic Education-Utilizing Computer-Based Collaborative Learning to Foster Lifelong learning Attributes. Family \& Consumer Sciences Research Journal, 38(3), 273 - 288. doi:10.1111/j. 1552-3934.2009.00018.x

Madar, A. R., \& Hashim, M. N. (2011). Effectiveness of using graphic animation courseware for students with different cognitive styles and spatial visual abilities. Journal of Technical Education and Training (JTET), 3(1), 47-58.

Mayer, J. (2014). The Cambridge handbook of multimedia learning ( $2^{\text {nd }}$ edition). Cambridge: Cambridge University Press.

Mohamed, S., Kamis, A., \& Ali, N. (2016). Gauging the assessment literacy of Malaysia's Home Economics teachers: An empirical study. Georgrafia Online, Malaysian Journal of Society and Space, 12 (3). $130-138$. 
Noah, S. M., \& Ahmad, J. (2005). Pembinaan Modul: Bagaimana Membina Modul Latihan dan Modul Akademik. Serdang: Penerbit Universiti Putra Malaysia.

Miza, N. A. R. (2015). Pembinaan Modul Berasaskan Pendekatan Projek Untuk meningkatkan Kemahiran Berkomunikasi Murid Tadika. (Doctoral dissertation, Universiti Sains Malaysia.

Pusso, B., \& Ahmad, A. (2016). ICT skill among Iban students in Sarawak. International Conference on Education and Regional Development 2016 (ICERD2016). "Cross-Culture Education for Sustainable Regional Development".

Rahman, R. A., Hasbullah, M. A., \& Zahari, M. S. M. (2016). Modular System and Students' Psychomotor Performance. Journal of Tourism, Hospitality \& Culinary Arts (JTHCA), 8(1), 17-34.

Reeve, E. M. (2016). 21st century skills needed by students in technical and vocational education and training (TVET). Asian International Journal of Social Sciences, 16(4), 65-82. Retrieved from http://aijss.org/index.php/aijss20160404/

Rubi, D. M., Mohamed, S., \& Sulaiman, N. A. (2014). Analisis pengetahuan isi kandungan komponen pakaian dan jahitan guru pelatih UPSI dalam bidang Teknik dan Vokasional. International Seminar on Technical and Vocational Education 2014 (TVEIS 2014), 143 156. UTM

Russell, D. J. (1974). Modular Instruction. A Guide to the Design, Selection, Utilization and Evaluation of Modular Materials. USA: Burgess Publishing Company.

Sarkar, S. (2012). The Role of Information and Communication Technology (ICT) in Higher Education for the $21^{\text {st }}$ Century. The Science Probe, 1(1), 30-41.

Schrum, L., \& Levin, B. B. (2015). Leading 21 $1^{\text {st }}$ Century Schools: Harnessing Technology for engagement and achievement. USA: SAGE Publications Ltd.

Smaldino, S. E., Lowther, D. L., \& Russell, J. D. (2012). Instructional Technology and Media for Learning. (10 ${ }^{\text {th }}$ Edition). Boston, MA: Pearson Education.

Talib, O. (2013). Asas Penulisan Tesis, Penyelidikan \& Statistik. Selangor: Universiti Putra Malaysia, Serdang.

Wingo, M. T., Thomas, K. G., Thompson, W. G., \& Cook, D. A. (2015). Enhancing motivation with the "virtual" supervisory role: a randomized trial. BMC Medical Education, 15:76 doi10.1186/s12909-015-0348-8.

Yanika, K., Moon, F. C., Sharon, S. L. T., Alan, S. K. S., \& Sally, W. C. C. (2017). Development of an e-learning Research Module Using Multimedia Instruction Approach. CIN: Computers, Informatics, Nursing, 35 (3), 158-166.

Yap, W. L. (2016). Transforming Conventional Teaching Classroom to Learner-Centred Teaching using Multimedia-mediated learning Module. International Journal of Information and education Technology, 6(2), 105-112 doi: 10.7763/IJIET.2016.v6.667

Yasak, Z., \& Alias, M. (2015). ICT integrations in TVET: Is it up to expectations. Procedia-Social Behavioral Sciences, 204(2015), 88-87.

Yuksel, H., \& Yuksel, A. (2015). The effect of the computer assited instruction on the academic achievement and retention of technical programme students' in vocational foreign language. Procedia Social and Behavioral Sciences 174(2015), 2513-2518. doi:10.1016/j.sbspro.2015.01.924 
INTERNATIONAL JOURNAL OF ACADEMIC RESEARCH IN PROGRESSIVE EDUCATION AND

DEVELOPMENT

Vol. 9, No. 2, 2020, E-ISSN: 2226-6348 @ 2020 HRMARS

Zakaria, A., \& Aisyah, N. (2017). Transformasi PTV: Kesediaan guru vokasional dalam pelaksanaan pengajaran Kursus Seni Kulinari. Journal FamilyEdu. 111(2), 65-72. 